\title{
An Interview with Danny Morrison
}

Interviewer: John F. Morrison ${ }^{1}$

Biography: This interview took place in the home of Danny Morrison, in west Belfast in March 2015. While no longer a prominent figure in Sinn Féin, during the Troubles alongside Gerry Adams and Martin McGuinness he was one of the most recognisable faces of the republican leadership of the late 1970s and early 1980s. The former Provisional IRA prisoner was the Director of Publicity for Sinn Féin and was the founding editor of An Phoblacht/Republican News. For many he is best known for promoting the dual paramilitary and political strategy of 'the armalite and the ballot box. $^{2}$

Context: In the immediate aftermath of the interview, it was announced by Sinn Féin was going to oppose the passage of the welfare bill in the Northern Assembly. ${ }^{3}$ While this was a key issue, which almost brought down the Stormont Assembly, the interviewer, and possibly the interviewee, was not aware of it at the time of the interview. Two days prior to the interview, the 2015 Sinn Féin ard fheis (annual conference) had finished in Derry. Throughout the ard fheis, various delegates outlined the party's plans to mark the centenary of the 1916 Easter Rising. However, while the party was celebrating their past achievements and future plans, they were once again being accused of involvement in criminality. The family of Paul Quinn, murdered in Cullyhanna in 2007, once again accused the Provisional Movement of being responsible for his death, a claim rejected by the party's leadership. ${ }^{4}$

\section{John Morrison: I was wondering if you would be able to give your assessment on the relevance to you as an individual of the centenary of the 1916 Rising, also how you feel it is relevant for the overall Republican Movement as well.}

Danny Morrison: I must begin my answer by pointing out that the attitude of the Irish government towards it has been disastrous. In their first promotional video for the centenary they didn't even mention the 1916 leaders. It reminds me of the Pope (John Paul II) when he came to Drogheda in 1979 and spoke about Oliver Plunkett but didn't discuss how he lost his head. It is because of course, in the case of the Irish government, they are embarrassed by the whole event. We have a former Taoiseach (prime minister of Ireland) John Bruton actually calling for it not to be celebrated and to celebrate instead the proposed passage of the third Home Rule Act, when it was enacted, although immediately suspended because of the First World War. I think that they are also quite concerned that people who haven't been subjected to twenty years of Section 31 (of the Broadcasting Act), that is the new young people that are around, and that have seen republicans in the flesh and have followed Sinn Féin.

They will probably be able to make up their own minds if they see parallels between 1916, the Tan war and the recent IRA armed struggle. I think that the government fears that as well, because of course what it does expose is that the Proclamation 
which they pay lip-service to, which probably hangs up in the Taoiseach's office, which they celebrate at Easter commemorations every year officially at Arbour Hill. They have done nothing to enact the statements contained in it, which are quite radical statements, and I would consider to be quite a radical document. Again they cannot rebut the argument that they have perpetuated the problem, initially in terms of the Treaty, which led to a split in the IRA, which led to a civil war in the South. The effect of it of course was that the 26 counties became quite insular. Certainly in recent years they have tried to create this whole notion that the nation stops at Dundalk, trying to turn the 26 counties into Ireland, ignoring us in the north as we were ignored historically. Having been ignored historically this was one of the reasons why there was the failure of the civil rights movement, and why the armed conflict erupted in the North. I didn't start it. I was born into the situation. My coevals did not start it. Again it was forced on us and we were found in a position where we were voiceless. Despite all promises of reforms no reforms came through and what we got was the British Army and emergency laws, the curfew, and internment and Bloody Sunday and etc.

So I think that 1916 is a very important event in Ireland's history. I think that the centenary of it is going to be extremely important. Already symbolically Sinn Féin are going to be holding the mayorships in Dublin in Cork and in Belfast in 2016 in those three cities. I think that people cannot help but see that those who pledged and promoted 1916 the most was the mainstream Republican Movement. It is no accident that in the European elections of last year that Sinn Féin became the largest party in Ireland. More recently at its annual conference, at its Ard Fheis in Derry, Martin McGuinness announced that it was their aim to be the largest party in the South and the largest party in the north in 2016. I'm not sure if the Assembly elections fall next year but certainly there is going to be a general election in May. So there will be a lot of emotion attached to the centenary and these elections.

Sorry just to jump back a wee bit. The government has also done nothing to preserve that area, the Moore St. area (in Dublin) which was the last place where the insurgents were before they were captured, or before they were surrendered. They are just going to let that go derelict. They have no problem of allowing the past to disappear, because it suits them.

In 1966 West Belfast hosted a big celebration - the entire road was covered in tricolours and bunting. Interestingly the government banned trains from the South on that day to limit people from attending that march. There was a great buzz around 1966. From a personal point of view I remember that our school in Andersonstown we participated in an All-Ireland drama competition and we came first at the Gate Theatre. I was a Russian serf and had very few lines to speak. But going down on the school mini-bus we were all singing 'We're on the One Road/Singing along/Singing 'The Soldier's Song'. There was this whole feeling of celebration and pride. Then of course there was lots of books brought out at that time. I think the last part of Walter 
Macken's trilogy, the last part was called The Scorching Wind, and it dealt with 1916, the Tan War and the Civil War. The other two books were Seek the Fair Land, that was the first one about Cromwell and Drogheda and driving the people 'to hell or to Connacht'; and The Silent People, which was about the Famine. So that was the sort of literature that we were devouring.

Along with that, and I can only speak for myself where I live, we also were following, the build-up and the intensification of the Vietnam War. We had Radio Caroline, a pirate radio station, belting out pop music. Because what you have got to understand is that the BBC didn't play pop music, not until 1967 when Radio 1 was set up. So we had Radio Caroline and we were listening to pop music, and American pop music and songs that were anti-war. What we could watch on T.V. was quite heart-breaking, so there was also an international element to our informal political education. I remember Czechoslovakia and Russia overthrowing the Dubček government in August 1968. And then of course 1968 witnessed the first civil rights march, the big one which Adams spoke about in his Ard Fheis election address when he compared Selma to Duke St. The $5^{\text {th }}$ October Civil Rights March was the first one ever caught on television camera. An RTE camera crew captured what was going on, the beatings, and how the Northern state routinely put down political protest from the nationalist community. In Selma it was actually the same thing that happened there, fifty years ago. For the first time it was caught on television and people were appalled by the southern police and how they were treating black people and Martin Luther King.

That was the civil rights movement. I think that 1966 helped to frame your consciousness in a certain way. But, and I have stated this time out of number, it wasn't 1966 and it wasn't 1916, and it wasn't the fact that I had an uncle in the IRA who was sentenced to death in the 1940 s, that made me a republican. I would say that what convinced me was the situation on the ground, what was happening to neighbours, what was happening to friends, the lies that we were told, the things that we were promised. As I said to you, we were promised reform and all that we got was the jackboot of the British Army. Of course you always thought of 1916, the Republic, the amount of music and poetry that came out of that period. I have written also before about the Foggy Dew and the powerful lyrics in it. "Twas far better to die neath an Irish sky, than at Suvla or Sud el Bar," talking about those who went off under Redmond's encouragement and those who stayed behind to fight for their country. So it is an interesting period.

I don't rely upon the fact, and I think that this is an argument that Prof. John A. Murphy has made and other revisionist historians have made. I don't rely upon the fact that they didn't have a mandate. That represents no crutch to my argument, because my argument is that the mandate that the IRA had came from local circumstances and local conditions and local repression. So mostly the ghettoes fought, the poor rural areas fought from 1970 onwards, until the ceasefire. The Republican Movement never claimed to represent the majority of the nationalist 
community. What they claimed to represent was the majority of those who were repressed, that's a distinction. Yes the IRB and Irish Citizen Army were undemocratic in that they struck in 1916. But proof of how inspirational it was the wipeout of the Irish Parliamentary Party within two years in December 1918. They disappeared from Irish history and Sinn Féin takes over.

JM: Going back to that initial point that you raised in relation to the Irish government, and you mentioned about John Bruton talking about 'repositioning history'. I can't help but think that this is a very similar narrative that the socalled 'dissident republicans' are now saying about Sinn Féin. They are saying that Sinn Féin have sold out on Republican ideals, how Sinn Féin have sold out on the 1916 ideals. How do you view that and how do you view the current dissident republican movement?

DM: First of all a lot of these people are anonymous. They cannot put their head above the parapet. They do not provide any form of public leadership. I think that there is an element amongst some of the younger ones - although most of the ones that get arrested aren't that young - that they missed the boat. They think that it must have been very exciting during the armed struggle 'I wish we had it.' There is a tiny element of that involved. I have no apology to make. I look around at people like Pat Sheehan who was sentenced to twenty years in jail and served ten. He was out eighteen months. He was arrested and charged with having a bomb. He was sentenced to another twenty years. He served ten. During his first term of imprisonment he was on hunger strike for fifty-five days and in fact was the longest man on hunger strike when the hunger strike ended in October 1981. He is now a Sinn Féin MLA for West Belfast. I look at Raymond McCartney who served life imprisonment and then had it overturned when it was shown that there was police corruption involved in his case. He was fifty-three days on hunger strike he is now an MLA in Derry. I look at Martina Anderson who served fourteen and a half years jail in England. She is the Sinn Féin MEP for the North. She got the highest vote of all the candidates. So I don't think that these people are in a position to lecture me or my comrades about principles.

All I know is this that whenever I was in the Republican Movement and whenever we were arrested our policy was not to plead guilty because that was criminalising not only our cause but in our most recent memory the hunger strikers. Ninety nine per cent of dissidents as soon as they are getting into jail are looking for a solicitor and plead guilty. 'I'm sorry your honour that I got involved. I'm sorry that I planted this bomb...I'm sorry this, I'm sorry that. Let me out early." That's the reality of it, and then they're going to turn around and say to us "you've sold out." Well, we didn't sell out.

The point about it is, the struggle might be over for them but the struggle isn't over for us. The proof of that is the unionist reaction claiming that Sinn Féin are using 
politics to fight the war by other means, that they are involved in attacking their culture, which is not true. What Sinn Féin did, and what the Republican Movement did, of course it compromised. That was the honourable and the right thing to do at the time. The IRA was well armed. It could have gone on to fight for another twentyfive to thirty years. I doubt very much if it would have altered their negotiating position or improved their negotiating position. In the meantime a lot of young people would have died, British soldiers, RUC people, Republican volunteers and members of the nationalist community. So that was the right thing to do. Of course we didn't end partition, nobody is claiming that that is the case. But what people are claiming is that the objective is still to remove British interference in our affairs and to allow the Irish people, in any way they want to configure it, to represent themselves and to move towards an all-Ireland economy provided it makes social, economic and political sense. You can win that case provided you can tick those boxes. That is the project. Reconciling ourselves with the unionist community, because of the damage that the conflict did to all sides. Nobody has got clean hands, despite what some people claim. So that's the project.

I don't see how the dissidents with their campaign... They will never be able to replicate the tempo of the IRA campaign and why is that? That is the question. Why is it? It is because the nationalist community no longer feels vanquished. It is because they are very, very proud of their elected representatives who...There is an interesting quote by a former Labour minister who was involved in negotiations in which he praises McGuinness and Adams just saying that they were streets ahead of others. These people weren't trained as negotiators. It is all instinctive, it is all natural, so to speak. So what they have produced is a transformed situation. There is no office in the north of Ireland not open to me as a citizen.

Now there is still discrimination. Ex-prisoners are still discriminated against. They can't adopt children, up until quite recently. I'm not even sure if this has been changed yet. They weren't allowed to apply for taxi licenses. There is a whole range of stuff. That riles with people. You had of course the SPAD (Special Advisors) bill, which the SDLP allowed to be introduced by not supporting a motion of concern by Sinn Féin. Paul Kavanagh, who is married to Martina Anderson, who also did fifteen years in jail and who is working and doing good work with Martin McGuinness at the Executive, was removed from his position as a result of that SPAD bill because he was a former sentenced prisoner. That is discrimination again. Of course you have Tom Elliott the former leader of the Ulster Unionist Party just last week giving notice that he was going to move a motion that no public amenity can be named after quote unquote a 'terrorist' and the SDLP committed that they would go along with it. They are committing political suicide. I don't know where they are getting that advice and direction from because it is pure madness. It opens up all sorts of crazy situations. What are they going to do change the name of Casement Park to suit Tom Elliott who is a Grand Master in the Orange Lodge? These are all the pitfalls. All the streets down the Falls, down the Clonard are all named after British battles. What are they going to 
do change all of those? No, no, no the only people they are talking about are Republicans when it comes down to it.

\section{JM: How do you assess the dissident threat?}

DM: The fact of the matter is that an armed struggle is only justified provided it has the potential to bring about real change, substantial change. It was a moral question, which the IRA faced in 1994. Senior British Army officers were admitting that they couldn't defeat the IRA and the IRA had to admit that despite being well armed they probably would not be able to significantly alter the situation without changing tactics. If they used terrorism they might achieve something, but that would be totally incommensurate with the degree of oppression, which we felt. We're not Palestinians. We're not down in the ground, beaten into the ground the way the people in Gaza are. So you could never, if ever there was any justification for anti-civilian bombings. Certainly it never existed in our case. So if you turn around and say, 'well what if the IRA had just systematically just blown up the Tubes? A load more bombs on the Tubes.' Would Britain not have reacted? Well they could have reacted with massive oppression. I doubt very much if they would have set the precedent of dealing with you on that basis and it would be totally immoral to use that strategy.

So what the IRA could do was circumscribed by a certain notion of ethics or morals in terms of what was permissible and, within those confines, to fight on would have been to condemn people to death in perpetuity and suffering in perpetuity. This is the same difficulty that the dissidents have to recognise. They're not going to change things. They're not going to change our minds. They're not going to force Sinn Féin to withdraw from the Executive over the condition of some prisoner in Maghaberry, because we are involved in a much bigger picture here. The other thing about it is that what they are actually saying to us is that 'you don't have a say. What you went to jail for doesn't matter. We're the tail. We're going to wag the dog.' That is completely unacceptable. As I say very few of them are prepared to publicly debate. They snipe from the sides; they snipe on Twitter and Facebook etc. More than ninety per cent of them, in my opinion, very few of them fight their cases. So how can they go and say you have no principles when they go and appeal to a judge for clemency or leniency.

\section{JM: Looking back on the Troubles and talking about morals do you feel that there were significant situations when that moral line was crossed by the Provisional Movement?}

DM: I think that the line was crossed by all of the protagonists. The difficulty I have is that the majority of times that I am asked this question on TV or radio, and I was asked the same question last Friday on the Nolan Show and I gave the same response that I will give to you now. I don't mind answering that question provided it is put to all the protagonists. It is never put to a Secretary of State 'that child who was killed by a plastic bullet, was that murder?' But I am asked to make a judgement if the IRA committed an act of terrorism or if killing someone was murder. Jeffrey Donaldson who is a DUP MP actually said that Bloody Sunday wasn't murder because it was 
carried out by the state and therefore it is legal. So they have a different attitude towards morality. If the government says that it is okay that makes it moral? No, no it might make it legal but it doesn't make it moral. Similarly with the Republican Movement, and there were unconscionable things that happened during the conflict in which innocent people lost their lives in horrific circumstances for a variety of reasons. Up until a few years ago I would have argued that on Bloody Friday the RUC and the British Army didn't act on the warnings that were given. But I am now of the opinion that the IRA overestimated the ability of the police to act and that they couldn't cope. They were overwhelmed by twenty-one bombs being placed around the city and in some places in Oxford Street and in North Belfast the warnings didn't get through and people were killed in horrific circumstances, including a young boy at the top of the Old Park Road, a young boy called Parker I think his name was. So there are other things that have happened as well. I don't want to itemise them because I don't want it to come back to haunt me and comrades coming back saying 'why are you surrendering that piece of information when there is no balance involved?'

What I will say is yes there was unconscionable things happened and they shouldn't have happened. We can't undo it. The Republicans paid a price in support at the time, like for example with La Mon there were people who told the IRA to get out of their houses that they're not going to sleep there anymore or 'get that (arms) dump out of my house, I've had enough.' Also of course some of those people three months later would have softened their opinion because they would have seen the way the state used it. In the case of La Mon for example the following Sunday the RUC went around the churches in West Belfast and placed this horrific photograph of a shrivelled body, which was someone's son or brother or sister. They put that on car windshields. I think that that would have annoyed people because they would never have made the same effort for a state killing or for a Loyalist killing. So people saw this the way it was being used and that softened their criticism. They were still critical of the IRA for carrying out that bombing.

If they had been a Republican before and had fallen out with the IRA over some bad bombing, they probably would have moved back towards the IRA or at least a proportion of them would when they viewed it in the round.

The IRA had support. There is no way the IRA could have gone on all those years without a substantial base of support. Just look at our street, now I am only going to tell you this anecdotally. If you go down Iveagh Parade which consists of forty houses Number 11 Paul Fox is interned, Gregory Fox is interned, Paul Fox after he gets out of jail is killed in an IRA operation. Further down the street I go to jail, my brother goes to jail for twenty-five years. Further down the street Ted Howell goes to jail three times, his brother Jim is assassinated by the Loyalists. Across the street the two McLarnan brothers go to jail. Further up the street Paul Gormley goes to jail. Further up the street Geordie and Eddie Duffy go to jail. Eddie Duffy is one who those who 
was tortured and whose case was taken to Europe by the Irish government in 1972, after the 'Hooded Men.' He was tortured and they tried to drown him in a bucket full of disinfectant and broke his arm in three places. That's our street. Each of us have cousins, school-friends who know that the demonising and derogatory remarks by a Secretary of State on the television or by Brian Faulkner about IRA Volunteers does not fit the description of the guy who they went to school with or who is their cousin. So there was a complete disconnect and people here very, very, very early became quite conscious of what propaganda was. It was remarkable. People in Britain might still be fooled by certain things but here there was a cynicism right away, even when letters appeared in the Irish News 'I'm a Catholic mother of four get the IRA off our backs.' People will be saying that's the British Army who wrote that letter. That's how cynical it would have been.

JM: You mentioned the propaganda. Obviously the role you are most famous for within the Republican Movement was as a publicity officer. How did you come into that role and how important do you think that was for the Republican Movement?

DM: Well, I remember writing in a diary in 1970 that I wanted to be a writer. In 1969 I had made a transmitter which was given to the IRA for Radio Free Belfast. That was broadcast above the Long Bar in Leeson Street, which interestingly was owned by a man called Paddy Lenihan whose daughter was Mary McAleese, who went on to become president (of Ireland). So I had already been involved in Radio Free Belfast. I sold ballot tickets to help raise funds for guns I suppose. It wasn't said so explicitly but that's what we understood it to be. I started to sell Republican News around the summer of 1970. 1971 I bought a typewriter with the intention of writing poetry and short-stories but the first thing I wrote was a letter to the Irish News complaining about the British Army shooting dead a guy called William Halligan down on the Falls Road.

By the end of '72 I was interned, November' 72 I was interned. I did A-Level English literature in jail. About a year after I came out of jail, in 1975 the IRA called a ceasefire and I was asked by Billy McKee if I would be capable of editing Republican News. I was 22 years of age I jumped at it. So I suppose whatever purported qualities I had or talents for writing fiction or for writing letters or composing statements I brought that into the publicity with me, and then learnt. For example up until 1978 if you were interviewing me you wouldn't know who I was. I ended up using different names even though I was editor of Republican News. It wasn't until we were all arrested Tom Hartley, myself, and Marie Moore and Danny Devenny, fourteen of us were arrested who worked on Republican News and we were charged with IRA membership and conspiracy to pervert the course of justice.

I represented myself in court and eventually got bail, we all got bail. We started a campaign for free speech and eventually the charges were dropped. It was because I 
was arrested that I then decided now I am going to say I am the editor of Republican News. I'm no longer going to keep it secret. Then whenever Republican News and An Phoblacht merged in February 1979 I became the editor of it and we slowly started to train people. Well first of all we started to try to professionalise the paper. I also took over as Director of Publicity that year from Ruairi O'Bradaigh's brother Sean and it was a question of just learning on our feet, recognising people who were articulate and who could make an argument. I remember when the 'Demolish Divis' campaign was on, the campaign to demolish the Divis Flats, we put Joe Austin up and Joe had the 'gift of the gab' and then we realised 'we could be doing this on lots of issues. We could have a spokesperson on this, that and the other.' Our advice centres at this stage were also learning about social security, benefits, how the DOE worked, how planning permission worked, health service. All that range of stuff that a typical political clinic would operate or deal with. So we started to deal with those and increasingly stories of that nature made their way into An Phoblacht about social and economic conditions not just the war news, although I think most people bought the paper for the war news because you would sell that as being overly dramatic and the IRA would give the inside story whereas the Brits would minimise what had happened. So that is how I grew into it.

\section{JM: How important was the merging of the papers for the dropping of abstentionism and for the new young leadership to gain power internally within the movement.}

DM: Internally there had been a reaction inside the IRA to that disastrous 1975 ceasefire. People were being told that there were negotiations going on and the British were going to be leaving. And 'did you see Rolls Royce pulling out Belfast. That's them pulling their economy out before.' People were led up the garden path. Also that year Republicans were involved in sectarian incidents and sectarian killings. I don't know if the IRA officially were involved but certainly republicans were involved. That was seen as very bad leadership. So there was a bit of a challenge to that and the outcome was that the IRA in the north was given much more of a say. I think it was around late 1976 the Northern command was set up. Its task was to turn the thing around. A lot of people had drifted home as a result of that long ceasefire. They were going back into their families, seeing their kids on a permanent basis, and it was very hard to get people to go back to armed struggle. The Northern Command was set up to turn that situation around and to tell the Brits that the IRA hadn't been defeated by this phoney peace. Parallel with that and in Republican News Tom Hartley and I in particular were highly critical of Eire Nua. So that debate went on for some years and I suppose it took its toll on Ruairi (O’Bradaigh) and Dave O'Connell.

Whenever I took over An Phoblacht they saw themselves as losing another battle because while Eire Nua was still official policy to me it was quite unreal what they were proposing. I didn't know anyone in Connacht who wanted a parliament or anyone in Munster. Our argument also was the Unionists, because you're saying to 
them 'You will still be in the majority in the nine county Ulster' we just thought that was ridiculous. We thought that Unionists wouldn't buy into that.

Then of course you had the first hunger strike and the second hunger strike and the first by-election in Fermanagh-South Tyrone. We had been tied by an Ard Fheis position that was taken in late 1980 that we would not contest the forthcoming local government elections in the north that were scheduled for May 81. I spoke against taking part in those elections, myself and Jimmy Drumm. We were nominated by the Ard Comhairle to do that. But then whenever Frank Maguire died and we managed to get Bobby Sands onto the ballot with no split nationalist vote, and we won that. That campaign transformed everything. We had the world media coming in. Bobby Sands had already been known in Republican News through his writings. He had been in charge of publicity in the H Blocks. He had been the PRO up until Brendan Hughes went on hunger strike and then he became OC of the prisoners. He had written songs. Christy Moore had played his songs 'Back Home in Derry' and 'McIlhatton.' We had also published a poetry book by Bobby and some other writings either prior to his death or around about the time of his hunger strike. Of course he won and there was that famous photograph of him. The NIO were trying to put out a mugshot of Bobby, but it was too late. The press turned around and said 'they (the republicans) have established this iconic image of Sands, it's too late to change it.' And it would be seen for what it was.

So we then realised too late that we weren't able to contest the May local government elections which is where the Irish Independence Party came out and took a lot of seats especially in rural areas. The IRSP took seats in Belfast, the People's Democracy took two seats in Belfast and we weren't represented at all. Now there was an election in the South in June ' 81 and we decided to put up prisoners because the hunger strike was to end up running for seven months. We got Kieran Doherty elected who was on hunger strike and Paddy Agnew who was from county Louth, and also on the blanket, elected. That deprived (Charlie) Haughey's government of its majority and ever since then there has been a coalition government in the south of Ireland, for the last thirtyfour years.

The hunger strike ended in October and a new secretary of state came in. One of the first things Jim Prior said was that he had desire to have a fresh initiative. They gave a lot of concessions to the prisoners which calmed things down to an extent. Although they were still trying to forcibly integrate Republicans and Loyalists in the H Blocks. They were to lose that as well. So he announced that he was interested in calling an Assembly election and going for what was called rolling devolution. We in the Ard Comhairle, because we didn't know when this election was going to be called and it would be a nuisance to call on the Ard Fheis (annual conference), we put down a motion to the Ard Fheis that the incoming Ard Comhairle be empowered to make the decision on contesting the Northern Assembly election on an abstentionist basis. We 
just thought that this would be no problem and that we would just get it passed. But it turned out to be a lot more difficult.

There were a lot of people who were opposed to it. Their fear was that it was going to lead to a run down in the IRA. Interestingly some them who argued went on to become dissident Republicans. They were arguing that the election intervention was a one off, just on a prison issue. We borrowed the seat and now we have to hand it back. Fuck off, what we have we hold. So we had turned Owen Carron into a working abstentionist MP and the two election offices in Enniskillen and Dungannon were turned into advice centres. That's how we were working Owen. So Adams and McGuinness said 'you better get up there. Everybody has to get up and support this motion.' So that is when I got up and I made the completely spontaneous 'armaliteballot box' speech and we won. Then the following year Prior called elections for October ' 82 . I think that we got $35 \%$ of the nationalist vote, or $10 \%$ of the overall vote. That was the start of it. Now there were set backs along the way. Adams lost West Belfast in 1992. I stood twice for the European elections, once in '84 and the other time in ' 89 and there was no increase in the vote at all, same percentage. I think it was $13 \%$ or something like that but a lower turnout. I think I got 95,000 votes or something like that in '89. I was in jail during all the negotiations but I had a sense of what was going on. I was the chair of Sinn Féin in the H Blocks and was in support of the developments on the outside.

To go back a bit in the run up to ' 86 Adams had already taken over as president and Ruairi could see what way the writing was going because before the debate he had already booked the hotel where they were going to do their exit, their walkout. A lot of good people went with them. I remained friendly with some of them including the first General Secretary of Republican Sinn Féin Cathleen Knowles. I was sad to see a lot of them go. I don't mean to sound disparaging but they were too traditionalist. That's okay if you want to have a cult. But if you are trying to change society for the better. If you are trying to achieve something grand and ambitious then you have to learn to be a pragmatist. So the difference I suppose was that they were fundamentalists and we were pragmatists.

\section{JM: Richard O'Rawe would speak out against the role of the Sinn Féin leadership at the time of the hunger strikes. He has intimated that a deal was in place and the hunger strikes were extended just to build up the support. How do you react to this?}

DM: Well it's totally baseless. It's demonstrably baseless. Richard O'Rawe spends four pages in his book outlining in detail the alleged deal that I brought into the jail on Sunday the $5^{\text {th }}$ of July 1981 . Of course when Richard wrote this he hadn't cited any British government cabinet papers. He also said that I brought this in on Sunday. I met Bik (McFarlane) in the prison hospital. Bik went back to the wing. Richard was two cells away. Bik told Richard what I had said. Richard said 'this is fantastic. Lets 
write out and tell them that we accept it.' Richard says at 3 o'clock on the Monday afternoon Adams wrote in on behalf of the Army Council saying that you are not to accept it. Then Joe McDonnell died and Richard kept his mouth shut.

So lets go back to see what really happened. With our support and under our advice Richard wrote a statement. I think it was called the $4^{\text {th }}$ of July statement. I have had conversations with Brendan Duddy and I can't be sure... Brendan Duddy in my opinion might have phoned up the British and said that the Provisionals are compromising. He was telling us that he had been contacted by the British and that this represented something. So Martin McGuinness went to see him on the Saturday and on the Sunday because we knew that Joe was in a bad way. The argument was that Gerry Adams or Martin McGuinness should be allowed to go in and the Brits said no. So my name was put forward. I had been banned from the jail since the previous December which was the last time I saw Bobby Sands alive. So the Brits said 'okay Morrison can go in.' So this is what happened. Duddy was telling Martin McGuinness what the Brits were saying on a phone call to him. Martin McGuinness rang Gerry Adams in Belfast to tell Gerry what Duddy had told him. Gerry told me and I went into the H Blocks. Our understanding of it was that this was just the beginning.

So I went in and saw all the hunger strikers including Joe McDonnell who I had been in jail with earlier, whose mother in law had delivered me at the time of my birth. We were neighbours.

There was Joe. There was Kieran Doherty. There was Thomas McElwee. There was Mickey Devine. Martin Hurson was too ill to go along to that meeting. Laurence McKeown was there. They wouldn't let Bik come in to meet me with the hunger strikers. They let me meet him separately. So I told them all we knew and all we were being told through the contact was that all the Brits were talking about was own clothes and some interpretation of work. Joe McDonnell turned to me and said 'well if they want me to go off this hunger strike they have to send someone in here. We need to see them there and they need to be able to stand over it. We are not going to have another repeat of what happened at Christmas.' So I said 'right okay I'll be back. I'm going into the doctor's surgery here. I am going to phone Adams and tell him what you are saying.' I went out I had just finished phoning Adams. Bik arrived. Bik was brought in to see the hunger strikers. I told Bik what I had told the hunger strikers and as I got up to leave, or as I just finished on the phone call an Assistant Governor came into the room and told me to 'get the fuck out of the jail.' He took the phone off me and threw me out of the jail. I wasn't allowed back. That is the meeting you are talking about.

So now four years ago we can now see the British cabinet papers and Duddy's contemporaneous notes. There is a document of transcripts of telephone calls the date and the time between Duddy and London. 'Soon' is his codename. It is $5^{\text {th }}$ July 1981 and I'm now on my way to the jail, or I'm about to go into the jail and Duddy asks the Brits 'whats on offer?' This is in black and white. The Brits say 'we are not prepared 
to formulate a position for the cabinet until after Morrison's visit.' That's in their papers for Sunday the $5^{\text {th }}$ of July. Flick over to Duddy's papers. Richard says that at 3 o'clock on Monday in the afternoon that Gerry Adams wrote in that 'you're not to accept what the Brits are offering. ' You look at Duddy's diary the first offer doesn't come in until 11:30 on Monday night. So how could Gerry have refused an offer that we hadn't even seen? So Richard is caught basically totally exposed. But instead what he does is to then confuse the situation he uses the letter that Thatcher agrees to send on the Wednesday morning, which we never see by the way. I never saw any of these documents. This is all word of mouth from Duddy. We don't even know who he is talking to. The document that Thatcher... and Thatcher changes it. But there is no way what is in that document corresponds to four pages of what is in Richard's book where he outlines in great detail what I allegedly brought in on the Sunday.

Whenever the book came out and I was very critical of him he turned around to the papers and says that Danny Morrison has a cheek. Danny Morrison had a deal in his back pocket when he sat with relatives in Toomebridge on the $26^{\text {th }}$ of July 1981 and didn't tell them about it. I wrote back and said 'there you go this is what I mean about memory. 'I collapsed at Joe McDonnell's funeral and was taken to hospital in Dublin. I had Hepatitis. I was in Cherry Orchard Hospital for the next three to four weeks when Richard has me sitting with relatives with a deal in my back pocket that I don't tell them about. So Richard never left his cell, never met the Governor, never met the hunger strikers, never met the ICJP, never met Amnesty International. Met nobody.

If this was true would the British government not have leaked it? They did everything else to cut down Sinn Féin over the years. If you look at other documents, for example a journalist sent to me an unpublished interview with Sir John Blelloch who was a senior advisor, probably in intelligence, to the cabinet around this period in '81. He rubbishes the whole idea that there was a substantial offer. The other thing is this. Richard also claims that it was to get Owen Carron elected. The by election hadn't even been called and wasn't called until the $28^{\text {th }}$ of July. We had no control over when it was called. So this business that we got Joe to die and stretched out the hunger strike to get Owen Carron elected doesn't even hold water because that by election might not have taken place until the following year or 6 months down the road. So he is ascribing these powers to us which we don't even have. He said he wrote the book for the relatives but he never told them about it until it was serialised in the Sunday Times. He never came to Bik or to me and say 'Danny this is what I think happened, this is what I am saying what happened. What's your opinion?' So it was quite consciously...And of course Richard's politics aren't the politics of the Good Friday Agreement. He sees it as a sell-out. So we have all of those things on top of it.

JM: One of the most controversial parts for Republicans of the post Good Friday Agreement Northern Ireland has been the acceptance of the PSNI. How do you believe this has gone down? 
DM: First of all it was an extremely difficult decision and it was one that some people walked away. People walked away and you had the likes of Eirigi springing up and being strengthened by that decision. It was extremely difficult. It was also extremely difficult for the RUC. Because they are saying 'what did we die for? Are our names now mud?' I have spoken to former RUC men who feel that way. It was a very difficult decision. I can't quantify the degree of abiding resistance that exists to it. I think that people still have a problem about lifting the phone. You can understand that because for 40 years we were telling them that it was wrong to do that. So I think that there is a big problem there. The dissidents exaggerate everything. If you are stopped 'I was brutally searched.' Everything is exaggerated for effect. It actually loses its power to engage people if you take part in that rhetoric all of the time instead of calling a spade a spade.

But I support the PSNI and I have called upon people to join them. I don't think they have joined them in their required numbers in order to make the PSNI think organically as representing everybody in the north. I think that it is still tilted towards the Unionist community in a big way. We need to be very careful that those cultures and attitudes don't seep into it. It has to be professional. Of course there are the monitoring committees there. There is the policing board to oversee and to scrutinise. We have been very, very lucky that there has been no major disaster, that the PSNI opened fired on some car that was the same colour some joyrider was using or somebody who robbed a post office and then they kill a woman and three kids. Something like that there would obviously be awful. So we have been fairly lucky so far. But there would be criticisms that the PSNI don't act quickly enough when crime is reported. Again is that because they suspect that they are being brought in, lured into West Belfast or Ballymurphy? I don't know.

It was a difficult decision. It was the right decision. Supporting the judiciary is the right decision as well. I think that you have to make these difficult calls if you are serious and also proven to be serious. Your credentials right away...Everything you say 'Articles 2 and 3 were the raison d'etre of the IRA.' 'Okay we will get rid of Articles 2 and 3. We will amend them.' 'You won't go into Stormont.' 'Okay we will go into Stormont.' By the way the SDLP was the larger party when Sinn Féin signed into the Good Friday Agreement. That took a lot of courage from Sinn Féin because you were buying into something which you weren't able to influence at that stage in a major way or in a way that you would have liked to have. 'You have to decommission.' Well first of all they wanted sackcloth and ashes. They wanted photographs. They wanted Spielberg They weren't getting that. So everything which was asked of Sinn Féin Sinn Féin has complied with.

There was an interesting article anonymously written on Slugger O'Toole yesterday by a guy who claims to be a Unionist saying that he would never vote for a united Ireland but that 'at least with Sinn Féin they say what they mean and they mean what 
they say, unlike our crew, unlike our people.' So I think that there is kudos for Sinn Féin in being open.

The PUP and mainstream Unionists claim that 'Sinn Féin are out to kill our culture.' The Union Flag still flies over the City Hall (in Belfast). It just doesn't fly 24 hours a day 365 days a year. It flies whenever it's the corgi's birthday or the Queen's birthday or Remembrance Sunday. It flies for 17 designated days which is the same that it flies over public buildings in England. I don't see the Tricolour flying.

On Orange marches Sinn Féin said 'okay on the $11^{\text {th }}$ of July or the $12^{\text {th }}$ of July the bands can come past our houses. There will be no protests. But you're not coming back at half five at night when you are all pissed and drunk and breaking our windshields, and shouting abuse at our women and piss on our gardens and calling us 'Fenian bastards.' 'So here is a compromise yes go down in the morning but later just get a bus back.' You know in some of those cases they were driving back to that spot to walk home when they were already on a bus. It's been difficult and I think privately a lot of Unionists would concede that Republicans have attempted to go halfway and I think that that's good.

\section{JM: Do you think that post 1994 was the earliest that the Troubles could be brought to a close or do you think that the Troubles could have been brought to a close before then?}

DM: I think that they could have been stopped before, but we will never know. I think that if the British government had of been talking to the Republican leadership. I mean properly talking to them; not using intermediaries and not using phone calls. We saw the dangers of it again when we saw that ex-priest in 1993 slipped in and alleged to speak for Martin McGuinness and say that the war is over. Those words would never have come out of Martin McGuinness' mouth at that stage and certainly not to that guy. It could have been over at certain stages provided that that same template was going to emerge. For example if the Good Friday Agreement had of been signed in Easter 1969 not one person would have lost their lives. Could you imagine how the nationalist community would have viewed the Good Friday Agreement; power sharing, the police being changed, radical changes to the system. By the way we were also promised a Bill of Rights which didn't come through. The Irish language act didn't come through. They have reneged on several things and Sinn Féin has to keep their eyes on this Stormont House Agreement and be sure the cushioning of the welfare cuts aren't reneged on either.

I think yes that if people had been talking and engaging in dialogue rather than demonising much earlier I think that certainly Adams. I can't speak for Martin because I would be closer to Gerry. But I would say that Gerry, and probably Martin as well, would be up to proposing compromise at an earlier stage. But those things 
would have had to have been in place. The British were recognising. You can see it all now that they knew they were political. They let the prisoners out didn't they? The Brits had designated them as criminals. But now there is an amnesty. My brother got out after seven years and he was doing twenty-five. Now don't ask me when, maybe '82-'83, there could have been peace. The point about it is the hunger-strike transformed everything and the British government made those circumstances by withdrawing political status. We had relative peace in the jail. Some prisoners were shot dead trying to escape, some died of medical neglect. But no prison officer had lost his life. No prison officer had been attacked until the beatings in the H-Blocks and the withdrawal of political status happened.

So the Brits were of a mind-set certainly then and even if you come up to...If you look at it from their point of view, their counter-insurgency point of view. 'We have to get rid of internment, well we will replace it by lowering the standard of evidence in the Diplock courts. We will intensify interrogation methods. We will make sure that the judges have all the power that people have to prove themselves innocent rather than us prove them guilty.' Then they got greedy 'lets introduce supergrasses. Look at what's happening in Italy with the Red Brigades. Lets introduce supergrasses. What will that require?' Well it would require turning the law fucking upside down and people who were involved with killing giving them an amnesty if they would put five of their mates away.

So they went through a phase of that for four years. Shoot to kill came in '82. When it came in you could see the cops in Armagh when Stalker was brought in and then they got rid of Stalker. So if you look at it from the Brits point of view they were still actively trying to defeat the IRA through Loughgall. 'If anyone is caught in a compromising situation at all near a weapon or half a mile from a weapon, kill them and we will stand over that.' Then they also decided to streamline collusion with the loyalists by helping them get guns in from South Africa that were captured by the PLO in Beirut in '82. Handing over information like 'Danny picks his kids up from school at four o'clock in the afternoon and sometimes he goes here and sometimes he goes here. Here is his car.' Alex Maskey was up in the Gregory Hotel on the Antrim Road for lunch. A loyalist drives up sees him going in phones up the British agent, the UDA guy, Brian Nelson. He phones him up and says 'I think I saw Maskey going into the Gregory Hotel. He says 'did you get his number plate?' 'Yeah.' 'Leave it with me.' Brian Nelson phones Lisburn headquarters and says 'is this Alex Maskey's car? We spotted him going into the Gregory Hotel.' Your man says 'that's him.' The loyalists go in to kill Alex Maskey meantime Alex's friend didn't show up for the lunch so Alex left the hotel. But they came in to kill him.

That is what was going on. So when you ask the question of when could the talks have taken place earlier they would have had to cease their mind-set of trying to screw Republicans of trying to kill Sinn Féin councillors. Thatcher stopped Sinn Féin appearing on TV and radio. There were all of those attempts so we felt like we were 
in a ditch. We felt as if we were behind the barricade and that is what we had to overcome to engage in talks and peace and always suspicious of the British, always suspicious. Can you trust them to stand over this?

\section{JM: From the Republican Movements point of view what would have been considered a successful paramilitary operation? And likewise what would have been an unsuccessful operation?}

DM: There were many terrible events. You've got Enniskillen, you've got La Mon, Kingsmills, Donegall Street explosion, Bloody Friday. Against that you have the IRA attacking British Army helicopters in South Armagh. You've got the Brighton bomb attack on Thatcher and the cabinet. You've Warrenpoint or Narrow Water. Any IRA operation which required courage, high risk, was of a military nature, for me as a publicist writing in An Phoblacht was much easier to defend and to explain and to stand over. Internationally it would have been seen as a guerrilla action. So there were times when the IRA actually wore uniforms in parts of South Armagh and had checkpoints and did interviews. 'Panorama' filmed them 'This Week' filmed them. It gave the impression that they had somehow control of territory, even though the territory was in their hearts and their heads and not physically in land. But British Army could only empty their bins in Crossmaglen barracks, South Armagh by helicopter. They were terrified to go into certain parts of it.

All of those add up. Prison escapes, everybody loves prison escapes, except for prison officers. Look at the IRA they went under the wall, over the wall, through the wall, out the gate, out of Portlaoise by helicopter. They took over the H Blocks, shot their way out of the H Blocks, 37 of them. Those operations there young people and people abroad just turn around and say 'Wow!' The seven guys breaking out of Maidstone in the middle of winter and swimming across Belfast Lough. So escapes obviously were David against Goliath and David outwits Goliath. Those from a publicity point of view, they are a dream.

\section{JM: Looking forward where do you see Irish Republicanism going realistically in the next few years? And also looking back was it all worth it?}

DM: Bobby Sands famously said that 'our revenge will be the laughter of our children.' Basically what that means is that if we manage to create a better more equal society yes one can talk about the disproportionate cost of human suffering of human life. Everyone will have a different view on it 'you started it.' 'No you started it.' I have my view of history. I have my view of how it came about. I wish that it had never come about. I wish that there would have been reform in 1968/69 or that when the Brits came in, and we were very friendly to the Brits, we made sandwiches for the Brits. They slept in our house. I wish that they hadn't been used against the nationalist people in a way that completely alienated them and meant in Republican ghetto areas that people felt that there was no state, that the state was hostile to them. In all its 
manifestations. Be it people who were supposed to put employment into an area or people who were supposed to look after houses, or people who were to make sure that you had a proper vote, or that people were supposed to ensure that you were protected. On every matter the state let the people down and so the people turned to an alternative state and that alternative state was the Republican Movement. So I can clearly argue and I know in my head where I came into it and what I went through before I decided to support armed struggle. I have quoted before Plato's saying 'only the dead have seen the end of war.'

For the future I hope that Sinn Féin succeeds in its project. I would like to think that if they do get into power in the south of Ireland that they will be able to substantially shift wealth towards those who are in greatest need. So you are talking about all the public services. You are talking about education, health, pensioners, employment, housing, all of those issues. They will meet a lot of opposition. The right wing is very, very strong. Not only the right wing but you will get some pressure from Irish America or some sections of it to put pressure on Sinn Féin. But Sinn Féin are very good at resisting that. I remember a journalist turn around and say 'Adams is basically fucked. Adams can't go to Gaza because of Irish Americans. Adams can't go to Cuba because of Irish Americans.' Adams went and met Castro. Adams went and met Hamas twice I think. So this thing that Sinn Féin can't do certain things because of its backers is a load of balls. Sinn Féin will do what it feels is required, even if it means losing some friends or some support they will do what is right. So I would like to think that they will continue to grow. I would like to think that Sinn Féin in Dublin government would help the Executive in terms of ensuring that the cross border bodies do meet regularly, in terms of roads. There are certain wee things that can be done, gestures you could call them which don't cost hundreds of millions of pounds which would help community relations. The note was struck at the Sinn Féin Ard Fheis which I watched on television which was that reconciliation is very, very important. That is probably the next stage. Now many unionists want 'reconciliation' on these terms, our surrender, where we say to them, 'You were right about everything, we were totally unjustified in resisting.' That is not going to happen. Reconciliation has to be based on mutual respect and you have to be able to show that compromise is a two-way street and I think that some unionists in their hearts are saying 'Sinn Féin voted for the flag to fly over City Hall. That's big. Sinn Féin have said yes go marching in the morning but don't come back at night. That seems fair enough to me.' When they do march what do they do, they fucking play the Famine Song outside St Patrick's chapel going in circles. Then they claim - "We didn't know it was a Catholic Church!'

\footnotetext{
1 Danny Morrison and John Morrison are not related.

2 Tim Pat Coogan, The Troubles: Ireland's Ordeal and the Search for Peace. (New York, Palgrave, 2002) 282
} 
${ }^{3}$ Gerry Moriarty, "Sinn Féin accuses DUP of reneging on Welfare Commitments." The Irish Times, March 9 2015. Accessed March 12, 2015

http://www.irishtimes.com/news/politics/sinn-féin-accuses-dup-of-reneging-onwelfare-commitments-1.2132011

${ }^{4}$ Gordon Adair, "Gerry Adams 'Wrong About Paul Quinn Murder' say Family," $B B C$, March 6, 2015. Accessed March 12, 2015 http://www.bbc.com/news/uk-

northern-ireland-31764539 